\title{
The effect of the Great Recession on the employment growth of young vs. small firms in the Eurozone
}

\author{
Andrea Mina ${ }^{\mathrm{a}, \mathrm{b}, *}$, Pietro Santoleri ${ }^{\mathrm{a}, \mathrm{c}}$ \\ a Scuola Superiore Sant'Anna and EMBEDS, Piazza Martiri della Libertà, 33, 56127 Pisa, Italy \\ ${ }^{\mathrm{b}}$ Centre for Business Research, University of Cambridge, Trumpington Street, Cambridge CB2 1AG, UK \\ ' STATEC, National Institute of Statistical and Economic Studies of Luxembourg, 13, rue Erasme L-1468 Luxembourg
}

\section{A R T I C L E I N F O}

\section{Article history:}

Received 12 June 2020

Revised 11 November 2020

Accepted 16 November 2020

Available online 30 November 2020

JEL classification:

G01

M13

D22

L25

Keywords:

Great Recession

Employment growth

SMEs

Young firms

Financial constraints

\begin{abstract}
A B S T R A C T
This paper examines the uneven impact of the Great Recession on firm-level employment growth across firm size and age classes. Based on firm-level data from ten Eurozone countries, we show that, notwithstanding the negative impact of the crisis, young firms were the most dynamic group of firms and prime contributors to net job creation even during the recession. However, conditional on survival, young firms experienced a sharp drop in their employment growth rates, whereas small firms were mostly unaffected. By using industry-level measures of external financial dependence, we then show how financial frictions were a driver of the growth rates slowdown of young firms.
\end{abstract}

(C) 2020 Elsevier B.V. All rights reserved.

\section{Introduction}

Understanding the role played by small and young businesses in the process of economic growth has long attracted the interest of both scholars and policy makers (Acs et al., 2009; Audretsch, 2002). In recent years, new evidence has emerged on the substantial contribution of young firms to aggregate net job creation (Haltiwanger et al., 2013), which has led to a reassessment of previous studies that had stressed the importance of small firms (Birch, 1981; Neumark et al., 2011). However, the prominent role of young firms might not necessarily hold in times of economic distress. The available empirical evidence on how firms respond to recessions has yielded mixed results: some authors argue that downturns hurt large firms the most (Moscarini and Postel-Vinay, 2012; Varum and Rocha, 2013) while others argue that they are especially harmful to small (Gertler and Gilchrist, 1994) or young firms (Bartz and Winkler, 2016; Fort et al., 2013; Huber et al., 2017). The different results imply considerable disagreement over the mech-

* Corresponding author at Scuola Superiore Sant'Anna and EMBEDS, Piazza Martiri della Libertà, 33, 56127 Pisa, Italy

E-mail address: andrea.mina@santannapisa.it (A. Mina). anisms through which recessionary shocks propagate in the economy, including the role played by financial frictions.

Given the conflicting results found in the literature, in this paper we provide new and original evidence on the impact of the economic downturns on employment growth across firm size and age by exploiting the double-dip recession experienced by Eurozone countries from 2008. The crisis had a very uneven effect on European economies and it is essential to understand what types of firms were especially affected by the downturn across countries. This is even more important at the time of writing, when the COVID-19 pandemic is causing a new downturn that will require appropriate policy responses. Our study aims to identify whether small or young firms were most vulnerable to the crisis, and to what extent credit market frictions were behind different growth performances. Drawing on the econometric approach developed by Haltiwanger et al. (2013), we find that, conditional on survival, young firms were the most dynamic businesses in terms of net job creation, but suffered relatively more than small firms during the double-dip recession. Conversely, small firms were mostly unaffected by the recession and, if anything, performed better compared with the pre-2008 period. We show that these results are robust to the inclusion of labour productivity, thus indicating that 
the decline in the growth rates of young firms is not driven by lower efficiency.

Furthermore, we explore whether financial frictions can explain the drop in employment growth rates of young firms by using industry-level measures of external financial dependence as in Rajan and Zingales (1998). Results indicate that financial frictions play a significant role since the relative decline of employment growth is more pronounced for young firms operating in sectors with higher external financial dependence. We then extend the analysis to consider the heterogeneous impact of the recession on sectors and countries. We find that the vulnerability of young firms to this double-dip recession is particularly high within manufacturing and high-tech sectors, and higher for peripheral than for core Eurozone economies.

The paper is structured as follows. Section 2 reviews the relevant literature. In section 3 we describe the data along with the econometric approach. Section 4 presents the results, section 5 provides a series of robustness checks and section 6 concludes with a reflection on the key results of the paper and their implications.

\section{Related literature}

In this section we review three strands of literature upon which our study builds. We start by discussing the research focusing on the relative importance of firm size vis-à-vis firm age in accounting for differences in firm growth rates; we next move towards those empirical contributions investigating whether economic downturns affect businesses depending on their size or age; we finally address one of the most prominent channels responsible for the greater fragility of firms during recessions, namely, financial frictions.

\subsection{Who creates jobs? Small vs young firms}

A vast literature has addressed the relationships between firm size, age and growth. In his seminal contribution, Birch (1981) documented an inverse correlation between firm size and growth. Since then small firms have regularly been regarded as a fundamental engine of job creation. Yet, more recent literature has pointed out that the contribution of small firms to job creation is extremely uneven (Hurst and Pugsley, 2011) and that it is not firm size per se that drives these results, but rather firm age (Haltiwanger et al., 2013). In fact, once firm age is conditioned on, there is no longer evidence of a systematic relationship between firm size and firm growth. In other words, young firms often happen to be small and the inverse relationship between size and growth is due to most young firms being classified as small. The relevance of firm age in explaining firm growth above and beyond firm size has been corroborated by several empirical studies in both individual and cross-country settings (Anyadike-Danes et al., 2015; Criscuolo et al., 2017; Huber et al., 2017; Lawless, 2014; Rijkers et al., 2014). Despite broad theoretical and empirical discussions on this topic, the literature has seldom examined these relationships during crisis periods. The empirical evidence on this matter is not only very limited but has produced results that are mixed and/or inconclusive, as we shall see in some detail in the next section.

\subsection{Small vs young firms during recessions}

The bulk of the research investigating the effects of recessionary shocks on firm performance has focused on the firm sizegrowth relationship. This mirrors the view according to which smaller firms are considered more vulnerable to the negative effects of an economic downturn. They may suffer disproportionately from crises because of their limited financial resources and dependence on banks lending with high interest rates. Furthermore, their greater reliance on fewer customers, suppliers and output markets may represent an obstacle in maintaining their previous levels of activity during a crisis.

As argued by Bartz and Winkler (2016), the literature on the impact of recessions can be classified in two categories: firm growth studies and business cycle studies. The former investigate the impact of recessions on the relative performance of firm of different size. The latter focuses on whether the nature of aggregate fluctuations depends on firm size.

Firm growth studies have found mixed results. For instance, Varum and Rocha (2013) find that, in Portugal, small firms show a relative growth advantage in recessionary periods (i.e. 1991-1993 and 2001-2003). On the contrary, Peric and Vitezic (2016) find that during the economic recession of 2008-2013, large and mediumsized firms exhibited higher growth rates than small firms in the Croatian economy. Popov and Rocholl (2018) report evidence for Germany indicating that large firms reduced their employment during the crisis more than small firms whereas the latter reduced wages more than the former. The authors argue that small firms, which are often family-owned, opted for adjusting the wage margin to provide greater employment protection in the presence of binding financial constraints. Alviarez et al. (2017) examine the growth performance of multinationals firms as opposed to those of domestic firms in 34 countries. Their results indicate that multinationals firms performed worse than domestic firms during the Great Recession. Since multinationals tend to be larger than domestic firms on average, this entails that larger firms performed poorly during the economic downturn.

From a business cycle perspective, prior research has investigated the link between macroeconomic fluctuations and firm size. Gertler and Gilchrist (1994) studied the behaviour of small and large manufacturing firms during episodes of contractionary monetary policy and an episode of credit crunch and found evidence that small firms experienced a harsher decline in their sales with respect to large firms. This is consistent with the financial frictions hypothesis, according to which small firms are more fragile during crises as they are more opaque, have less collateral and a less established track record than large firms. However, more recent research has challenged this view. In particular, Moscarini and Postel-Vinay (2012) provide evidence that the employment growth of large firms features greater cyclicality than the employment growth of small ones. This indicates that during economic expansion small firms face more severe "hiring constraints" than large firms because the latter are more productive than the former and, hence, can offer higher wages. During downturns, however, the increased labour supply makes it less necessary for firms to compete for a limited amount of workers. Thus, according to Moscarini and Postel-Vinay (2012), in recessions small size does not represent a liability, but rather an asset. Likewise, Kudlyak and Sánchez (2017), using the Quarterly Financial Report dataset, find that large firms' sales contracted relatively more than those of small firms during the 2008 financial crisis. ${ }^{1}$ Departing from the above-mentioned lit-

\footnotetext{
1 The conflicting results might be easily related to the different measures used to partition firms in size classes as well as to different dependent variables. In fact, while Kudlyak and Sánchez (2017) employ total assets to identify size classes (and sales growth as dependent variable) based on the seminal contribution of Gertler and Gilchrist (1994), others rely on the number of employees (Fort et al., 2013). Furthermore, Haltiwanger et al. (2018) document that the results of Moscarini and Postel-Vinay (2012) emerge due to the use of the HP-filtered unemployment rate to proxy cyclicality. In fact, high unemployment persists even once recessionary periods are technically over. Haltiwanger et al. (2018) use instead the change in the unemployment rate, which is better aligned with credit crunches. When using this proxy, they show that small firms tend to shrink more than large ones during recessions.
} 
erature, Fort et al. (2013) consider the role played by both firm size and age. Using the Census Bureau's BDS from 1981 to 2010, they show that it was young-small US firms that experienced the larger decline in net job creation during the Great Recession. Similar conclusions are reported by Colciago et al. (2019) who examine US data using a longer time horizon.

In contrast with the above studies, recent literature has stressed the necessity of accounting for firm age to better understand the impact of recessions. The fundamental intuition is that many of the hypotheses that have been developed to explain why small firms should be more sensitive to variations in economic conditions apply more precisely to young firms (Fort et al., 2013). ${ }^{2}$ These firms, while sharing many characteristics with small firms, might be particularly sensitive to recessionary shocks since they are more informationally opaque, lack collateralizable capital and a well-established customer base, and face stiffer competition from incumbents.

Only few contributions have explicitly considered both age and size in relation with firm growth during periods of economic turmoil. ${ }^{3}$ Bartz and Winkler (2016), while limiting their analysis to German SMEs, show that during 2009 small firms exhibit an advantage compared to larger ones. However, young firms seems to grow relatively less if compared with their more mature counterparts. Huber et al. (2017), based on the universe of Austrian firms, document that during the Great Recession (i.e. 2008-2010) the net job creation of young firms decreased whereas the relative contribution to net job creation of smaller firms increased.

To sum up, independently from the methodological perspective adopted, extant literature provides contrasting results on the impact of recessions on the age-size-growth relationships, which clearly requires further investigation.

\subsection{Recessions and the role of financial frictions}

Among the reasons why smaller and younger firms should be more vulnerable to downturns, the presence of financial constraints is a primary suspect (Hadlock and Pierce, 2010). Smaller and younger firms may struggle to obtain access to credit during recessions because of stronger effects of information asymmetries, lower collateral and lack of established relationships with financial institutions (Gertler and Gilchrist, 1994). Moreover, lending to smaller businesses decreased significantly during the Great Recession in both the US and Europe (Duygan-Bump et al., 2015; Fernandes and Ferreira, 2017).

\footnotetext{
2 As argued by Fort et al. (2013, p.526), "[f]or papers addressing the role of financial frictions, firm size is often used as the proxy for differential access to credit across firms even though it is undoubtedly a limited measure. Indeed, many of the papers highlight that firm age would be a preferable proxy but firm age is less readily available. For example, Gertler and Gilchrist (1994, p. 313) comment that "[t]he informational frictions that add to the costs of external finance apply mainly to younger firms"”.

${ }^{3}$ A recent strand of literature has focused only the performance of newborn firms across booms and bursts (Lee and Mukoyama, 2015; Moreira, 2017; Sedláček and Sterk, 2017; Zarutskie and Yang, 2017). They show that during recessions employment created by start-ups is more volatile and pro-cyclical and that firms born during downturns tend to start out and stay smaller relative to cohorts of firms born during good times. Connected to this aspect, another stream of literature has addressed what kind of entrepreneurs establish their businesses during recessions by distinguishing opportunity vs necessity-driven entrepreneurship. While the former refers to individuals starting a business when they see an opportunity, the latter refers to individuals forced into starting a business out of necessity because of the lack of other options in the labor market. Among others, Kelley et al. (2011) and Fairlie and Fossen (2019) provide evidence that opportunity entrepreneurship is pro-cyclical whereas necessity entrepreneurship is counter-cyclical. At the same time there is also historical evidence that some of the most radically innovative companies in their field such as Disney, Microsoft, Oracle, Hewlett Packard, Dropbox, Uber and Airbnb have been founded during recessionary periods.
}

A series of studies have investigated differential effects of financial constraints during the recent financial crisis in terms of firm size, and here again results are conflicting. Among them Chodorow-Reich (2014) shows that the financial constraints channel played a pivotal role in determining the employment decline at small and medium firms after the Lehman Brothers bankruptcy. Duygan-Bump et al. (2015) find that the probability of becoming unemployed during the financial crisis is higher for workers in industries with high external finance dependence, relative to those in industries with low dependence and that these effects are stronger for smaller firms. On the contrary, Popov and Rocholl (2018), using matched bank-firm data for Germany, show that in response to a negative shock to access to finance, firms with less than 20 employees are less likely to reduce employment. Similarly, Kudlyak and Sánchez (2017) find that large firms' sales contracted relatively more than those of small firms during the 2008 financial crisis. They also show that low financially-dependent firms suffered more than high financially-dependent firms thus claiming that financial frictions do not propagate via small firms or highfinancially dependent ones.

However, many of the underlying hypotheses according to which smaller sized firms should suffer more during economic downturns, are actually more relevant for younger firms. The only study that sheds light on the role played by financial constraints during the Great Recession on the employment dynamics of small and young firms is Siemer (2019). Based on the universe of US firms during the 2007-09 period, the author constructs an external financial dependence measure (Rajan and Zingales, 1998) at the sectoral level using Compustat, and employs a difference-indifferences identification strategy. The results indicate that financial constraints accounted for a stronger reduction in firm employment growth during the 2007-09 period and that this decline is primarily driven by small and young firms subject to high external financial dependence. It is not clear whether these results would hold for the European economy.

\section{Data and methodology}

\subsection{Data}

Our firm-level data are taken from Amadeus, a commercial database provided by Bureau van Dijk. We use two different Amadeus vintages (2011 and 2017) to construct our sample. We first selected those countries that adopted the euro by the time it replaced national currencies in 2002. We then extracted information regarding the non-financial private sector in these Eurozone countries between 2000 and 2016 largely following the strategy outlined in Kalemli-Ozcan et al. (2015). The final sample contains data for the following countries: Austria, Belgium, Germany, Greece, Finland, France, Ireland, Italy, Spain, and Portugal. ${ }^{4}$ We had to exclude Luxembourg and the Netherlands from the analysis because of the extremely scarce coverage of SMEs. We proceed to clean the data by dropping observations featuring missing or non-positive values for employees and age. Moreover, since our dependent variable will be firm employment growth, we selected only those firms with non-missing values for employment for at least two consecutive years. In order to control for possible anomalies or extreme values, we proceed to clean our sample by excluding those observations that lie outside the interval $\left[\right.$ Median $\left(\right.$ Employees $\left._{i}\right) / 10 ;$ Median $\left(\right.$ Employees $\left._{i}\right) \times 10$ ] where the median is calculated over the time-span for which data are available

\footnotetext{
${ }^{4}$ Note that Austria features observations starting only from 2004 whereas the sample for Ireland and Portugal has few observations until 2006 (see Table A1). However, results hold irrespectively of the inclusion of these countries in the sample.
} 
for firm $i$ (Bottazzi et al., 2014). We obtain an unbalanced panel of approximately 11 million firm-year observations and 2 million unique firms spanning the time period 2001-2013.5

Table A1 reports the sample composition across firm size and age classes for each of the countries included in the sample after data cleaning. Firms are categorised according to three size classes (employees $<50 ; \geq 50$ and $>250$ ). We observe that all countries (except Austria and Germany ${ }^{6}$ ) feature good representativeness in terms of firm size (i.e. small firms account for more than $90 \%$ of the whole sample). We also provide the sample distribution according to three age classes (age $<10 ; \geq 11$ and $>20$ ) as in Coad et al. (2013) and Navaretti et al. (2014). In this case, Amadeus does not feature an optimal coverage of young firms although those between 0 and 10 years of activity still represent the largest share (45\%). This figure is roughly in line with studies using richer single-country datasets such as Lawless (2014) for Ireland and Grazzi and Moschella (2018) for Italy. ${ }^{7}$

We want to assess whether there are differential effects of the crisis on net job creation. Hence, our dependent variables is the Davis et al. (1996) net employment growth rate (DHS, henceforth) to ease comparability with prior research addressing the relative contribution of firm size and age classes to net job creation (Haltiwanger et al., 2013; Huber et al., 2017). ${ }^{8}$ Let $E_{i, t}$ be employment in year $t$ for firm $i$, the DHS growth rate is computed as follows:

$g r_{i, t}=\left(E_{i, t}-E_{i, t-1}\right) / X_{i, t}$,

where

$X_{i, t}=0.5 *\left(E_{i, t}+E_{i, t-1}\right)$.

${ }^{5}$ The Amadeus 2017 disk provides data on 2015 and 2016 as well. However, the number of observations is extremely low for some of the countries included in our sample and, therefore, we do not include these two years in our analysis. Finally, since the recession ended in 2013, we excluded 2014 in order to create two well-defined pre-crisis and crisis periods. Note also that Amadeus drops firms from the database if they did not report anything during the last 5 years (KalemliOzcan et al., 2015). To test whether the reported results were subject to this survivor bias, we limit our sample to Amadeus v.2011 data and spanning the period 2005-2010. Results from all the above test are similar to the ones reported in the text, thus assuring that survivor bias does not represent a major issue in our analysis.

6 For Germany this is partly due to less stringent reporting requirements if compared with other European countries that allow firms not to file detailed annual reports and prefer to pay a small non-reporting fine (Kalemli-Ozcan et al., 2015).

7 The under-representation of young firms - common to most firm-level datasets (Coad, 2018) - has to be taken into account when interpreting our results along with the fact that our estimates are conditional on firm survival (we do not address the exit margin because, although the Amadeus database provides information on whether a firm is still active or not, it does not provide reliable data on the year in which exit actually occurs). This may affect the results in two opposite directions. On the one hand, the possibility that our sample may over-represent more successful young firm could generate an upward bias in the negative effect of firm age on growth thus overestimating the role of young firms. On the other hand, by using data on relatively larger (and older) firms, we may underestimate the effect of age. Finally, by not taking into account the exit margin we are arguably underestimating the effects of the recession on young firms'growth given their higher probability of exiting the market during downturns (Fort et al., 2013). Prior empirical research using Amadeus data has recurred to re-sampling techniques to achieve better representativeness in terms of firm size based on statistics of the full population of businesses (Gal, 2013). However, Gal (2013) shows that these techniques are successful only when re-sampling firms with at least 20 employees. Given that our analysis focuses on young firms, and that more than $90 \%$ of them have less than 20 employees in our sample, re-sampling techniques are not a solution to this problem.

8 We also replicate the analysis using growth rates computed as log-differences and obtain very similar results. Note that proportional growth measures (such as growth rates in log-differences) tend to be biased towards smaller firms, whereas absolute growth measures are biased towards large ones (Coad, 2009). To test the sensitivity of our results, we employed the Birch index (Birch, 1987) as an alternative measure of growth. This is a weighted average of relative and absolute growth rates, and is computed as $g_{i, t}=\left(E_{i, t}-E_{i, t-1}\right)\left(E_{i, t} / E_{i, t-1}\right)$ where $E$ is the number of employees for firm $i$ at time $t$. The results, reported in the Appendix, fully confirm our main findings.
Consistent with this strand of literature, the definition of firm size is based on the total number of employees averaged over two consecutive years (i.e. also known as the "average size" classification) which makes it possible to avoid the so-called regression to the mean bias (Davis et al., 1996). In fact, firms experiencing a negative transitory shock at $t-1$ are more likely to grow at $t$, whereas those with a positive shock at $t-1$ are more likely to shrink at $t$. Therefore, addressing the size-growth nexus using lagged firm size (often referred to as "base size" classification) is likely to produce results that are upward biased and that overestimate the contribution of smaller firms to net job creation.

In order to provide descriptive evidence on the possible differential impact of the double-dip recession on the growth rates of small and young firms we report summary statistics using aggregated size and age categories (see Table 1). Small firms are defined as having less than 50 employees and young firms are those having less than 5 years of activity. ${ }^{9}$ In Table 1 the top panel refers to the pre-crisis period (i.e. 2001-2007) and the bottom one refers to the crisis period (i.e. 2008-2013).

During 2001-2007, we can observe that young firms display growth rates that are higher on average and more skewed to the right hand of the distribution with respect to all other groups of firms. This is consistent with both prior evidence (Coad, 2018; Coad et al., 2013) and theoretical models such as Jovanovic (1982), which predict that young firms will experience higher and more volatile growth rates. If we turn to small firms, we can observe that the employment growth distribution displays thicker tails if compared to that of large firms. However, it features less skewness to the right relative to younger firms, indicating a lower probability of high-growth episodes. In other words, small firms are more prone to negative growth episodes, while the growth outcomes for younger firms are skewed positively: small firms have a greater chance of shrinking rapidly, while young firms have a greater chance of experiencing high growth.

During 2008-2013, all groups of firms experience a reduction in their average employment growth, and this is especially the case of small and young firms, whose whose growth rates experience approximately a $2 / 3$ reduction if compared with the pre-crisis period. In particular, we see that for young firms the probability of experiencing low-growth episodes is considerably magnified whereas there is a less marked reduction in the probability of experiencing growth episodes. We do see a similar behaviour for small firms but the probability of experiencing downsizing episodes is, however, not as high as the one experienced by young businesses. In contrast with young and small businesses, large and mature firms display employment growth distributions that are more centered around zero and with lower variance if compared with the precrisis period. This decrease in dispersion is driven by a lower probability of experiencing both downsizing and growth episodes during the double-dip recession. Overall, the descriptive evidence suggests that all firms have experienced a reduction in net job creation and that, among them, small and young firms have been hit particularly hard by the double-dip recession.

\subsection{Empirical strategy}

We draw on the empirical approach developed by Haltiwanger et al. (2013) and who estimate employment-weighted OLS regressions to examine the relative contributions of different size and age classes to net job creation. We begin by regressing DHS employment growth rates on size classes dummies alone,

\footnotetext{
${ }^{9}$ It is worth stressing that, as widely documented (e.g. Haltiwanger et al. (2013)), the overwhelming majority of young firms are small, but not all small firms are young. In our data roughly $98 \%$ of all young firms are small, whereas only around $20 \%$ of small firms are young.
} 
Table 1

Employment growth across firm size and age classes

\begin{tabular}{lllllllll}
\hline 2001-2007 & Mean & SD & p10 & p25 & p50 & p75 & p90 & $N$ \\
\hline Young & 0.11 & 0.38 & -0.21 & -0.01 & 0.01 & 0.23 & 0.56 & 887,704 \\
Mature & 0.02 & 0.23 & -0.13 & -0.04 & 0.00 & 0.07 & 0.18 & $3,898,998$ \\
Small & 0.03 & 0.27 & -0.18 & -0.04 & 0.00 & 0.10 & 0.29 & $4,378,048$ \\
Large & 0.02 & 0.23 & -0.11 & -0.03 & 0.01 & 0.06 & 0.17 & 408,654 \\
2008-2013 & Mean & SD & p10 & p25 & p50 & p75 & p90 & $N$ \\
Young & 0.04 & 0.43 & -0.33 & -0.05 & 0.00 & 0.17 & 0.50 & 974,148 \\
Mature & 0.01 & 0.22 & -0.14 & -0.04 & 0.00 & 0.05 & 0.14 & $4,974,699$ \\
Small & 0.01 & 0.29 & -0.23 & -0.05 & 0.00 & 0.07 & 0.25 & $5,501,384$ \\
Large & 0.01 & 0.21 & -0.11 & -0.04 & 0.00 & 0.05 & 0.13 & 447,463
\end{tabular}

Notes: the table reports summary statistics of employment growth rates pooling data across all countries and splitting them across the pre-crisis and crisis periods. Young firms are businesses under the age of 5 , mature ones are those with age equal or above 5 . Small firms are firms with less than 50 employees, large ones are those with 50 employees or more.

on age classes dummies alone, and on both size and age classes together. In our preferred specification, we use the average firm size classification (i.e. the average number of employees between $t-1$ and $t$ ) whereas we employ the base size classification (i.e. the number of employees at time $t-1$ ) to examine the bias derived by measurement errors and regression to the mean effects. In formal terms, we estimate the following model:

$g r_{i t}=\beta_{s}$ Size $_{i, t}+\beta_{a}$ Age $_{i, t}+\psi_{c, t}+\omega_{s, t}+\epsilon_{i, t}$

where $g r$ is the DHS employment growth as defined in the previous sub-section, Age represents a vector of age dummies whereas Size a vector of size dummies. In the regression analysis, we rely on more fine-grained age and size categories: we employ eight size classes (1-4, 5-9, 10-19, 20-49, 50-99, 100-249, 250-499 and 500 and more) and eight age classes (1-2, 3-4, 5-6, 7-8, 9-10, 11$12,13-15$, and 16 and more) to ease comparability. ${ }^{10}$ Furthermore, we include time-sector (2-digits NACE Rev.2) and time-country interactions to control for both country- and sectoral-level shocks. Additionally, since our goal is to understand which size and age classes are hit harder during the double-dip recession, we perform a split-sample analysis by partitioning the sample into two periods (i.e. 2001-2007 and 2008-2013). ${ }^{1112}$

The estimation of a fully saturated model (i.e. the one including both age and size classes as well as interactions thereof) would represent the best approach, since it yields unbiased estimates of the conditional means in each age-size cell irrespective of the distribution of the dependent variable (Angrist and Pischke, 2009). However, in our case, given the need to control for systematic differences across countries and sectors, opting for a fully saturated model would imply the estimation of all age-sizetime-country-sector groups encompassing all possible interactions across covariates (Huber et al., 2017). This specification would require the (computationally challenging) estimation of hundreds of thousands parameters and would produce results that would be difficult to interpret. Because of this, and drawing on prior litera-

\footnotetext{
10 These categories are employed by Haltiwanger et al. (2013). Note that, differently from these authors, we do not insert firms with age zero given that our analysis is conditional on survival.

${ }^{11}$ September 2008 is generally regarded as the onset of the crisis with Lehman Brothers' bankruptcy followed by the failures and bailouts of other major financial institutions and a sharp escalation in the global credit crunch.) In the Eurozone, based on the OECD Recession Indicators (https:/fred.stlouisfed.org/series/ EUROREC), countries suffered from two distinct recessionary periods: Peak 2008M2Trough 2009M6; Peak 2011M5-Trough 2013M3. In unreported exercises, we also tested alternative time spans (e.g. crisis period defined as 2007-2013) and found no major changes in the results.

12 In what follows we report estimates of Eq. (1) separately for the pre-crisis and crisis periods for illustrative purposes. For completeness we include the results from a nested model in which all size and age variables are interacted with the crisis dummy in Table A9 in the Appendix.
}

ture (Huber et al., 2017), we present visual evidence of the results using the simpler two-way model without interactions. We also estimated almost fully-saturated models with age and size classes and their interactions along with a full set of time-sector and timecountry fixed effects. Results are qualitatively very similar and they are available upon request.

\section{Results}

\subsection{Who creates jobs? Small vs young firms}

We estimate employment-weighted OLS regressions using both the base size classification (yellow and green lines) and the average size classification (blue and red lines) using the pooled sample (i.e. 2001-2013). As for the US economy (Haltiwanger et al., 2013), the base size classification overstates the role of firm size given that this measure is more prone to regression to the mean bias. Moreover, young businesses display higher growth rates conditional on survival (see Figure 1) highlighting very similar patterns to the ones found for US firms. In more detail, we can see that very young firms (those of age 1-2), exhibit employment growth rates that are $12 \%$ higher than those of firms older than 15 years when the average size classification is adopted (blue line). When we add firm size in the regression, the association between age and growth slightly strengthens (red line). This is expected given that younger firms, which tend to be small, grow faster than mature small firms. Finally, when using the base size classification, the role of firm age tends to be understated and the association between firm age and growth conditional on survival is less downward sloping (green and yellow lines).

We next turn to the relationship between firm size and employment growth. We observe that smaller firms grow more than larger firms when the base size classification is adopted. On the contrary, when the average size classification is employed, the relationship between size and growth flattens (blue line) and, when controlling for age, it turns negative indicating that smaller firms grow less than larger ones (red line). In fact, firms with 1 to 4 employees grow $1.7 \%$ less than those with more than 499 employees. In contrast with the findings of Haltiwanger et al. (2013), the inclusion of firm age does not induce firm size to lose statistical significance irrespectively of the size classification employed. ${ }^{13}$

\footnotetext{
${ }^{13}$ Yet, our results are in line with single-country analyses such as Lawless (2014) for Ireland, Grazzi and Moschella (2018) for Italy and Huber et al. (2017) for Austria. The fact that, differently from the evidence for the US, firm size does not lose statistical significance when including firm age when examining European data is a finding that calls for further investigation.
} 

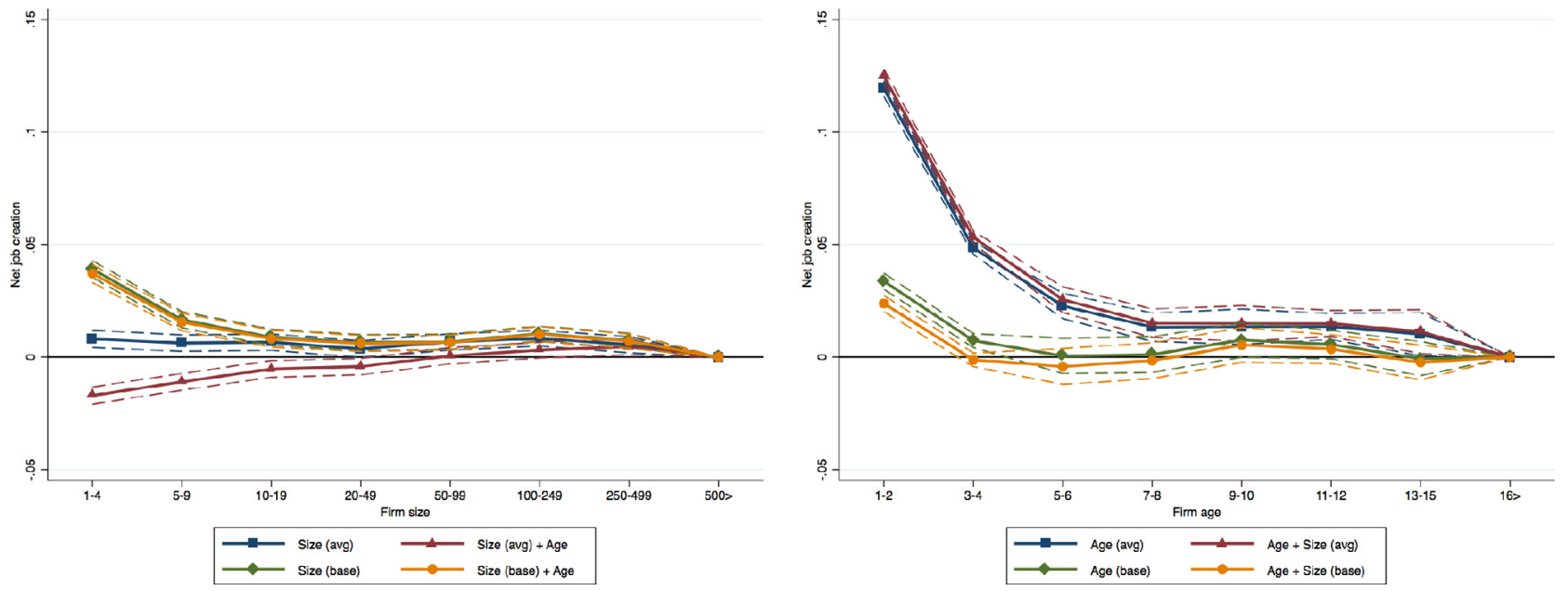

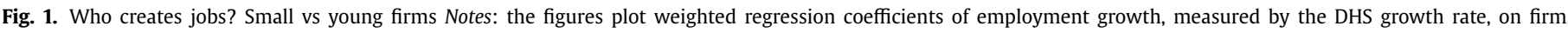

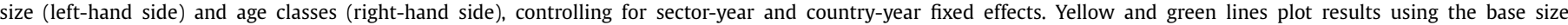

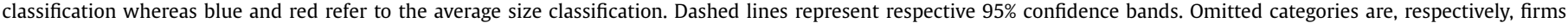

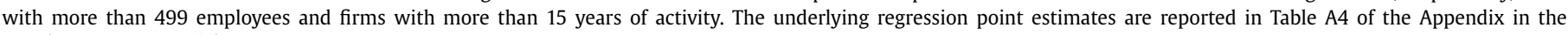
Supplementary Materials.
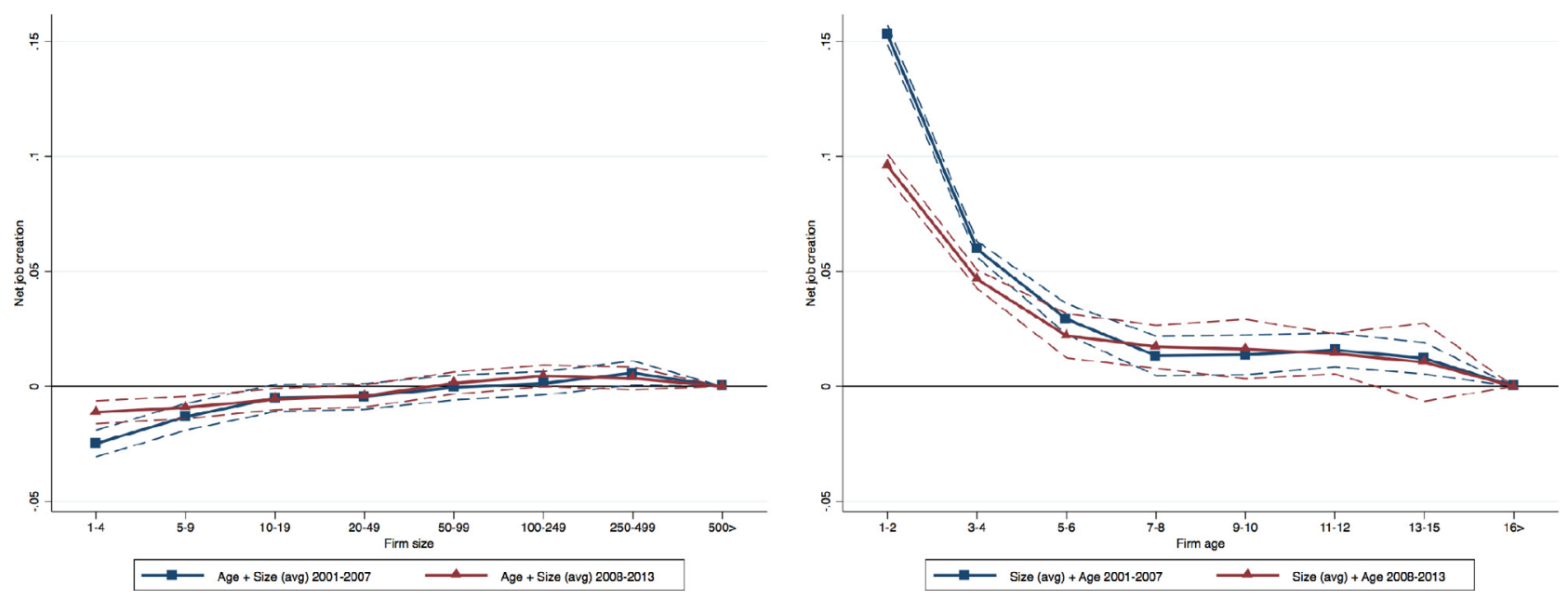

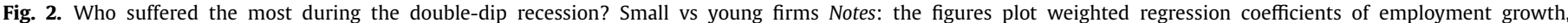

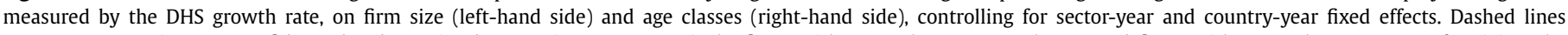

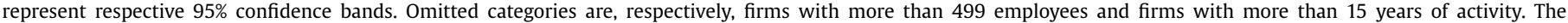
underlying regression point estimates are reported in Table A5 of the Appendix in the Supplementary Materials.

\subsection{Small vs young firms during the recession}

We now want to focus specifically on whether the age-sizegrowth relationships observed so far are altered during periods of economic distress. We estimate Equation (1) using the average size classification and splitting the sample across the pre-crisis (i.e. 2001-2007) and crisis period (i.e. 2008-2013). Results displayed on the left side of Figure 2 show that the relationship between firm size and employment growth is not particularly different across the two periods. However, we do observe a statistically significant difference for very small firms (i.e. 1-4 employees) which seem to have weathered the crisis better given that their growth rates increase from $-2.5 \%$ to $-1.1 \%$ relative to large ones. ${ }^{14}$

14 We also run our baseline model regressing employment growth rates against base size classes only for the pre-crisis and crisis periods. In this case the growth of small firms tends to be negatively affected by the double-dip recession which is consistent with prior studies (see Figure A1). This highlights the importance of
Differently from smaller firms, we do observe a considerable and statistically significant decrease for very young firms (i.e. age 1-2) and some negative impact for firms aged 3-4 as well (see right side of Figure 2). In more detail, while firms aged 1-2 have a $15.3 \%$ higher employment growth rates relative to older firms in the period prior to the crisis, they decrease their growth rates to $9.6 \%$ during 2008-2013. Notwithstanding this reduction in their performance, young firms are the most dynamic group even during the double-dip recession thus confirming their prominent role in contributing to job creation throughout the business cycle.

To sum up, consistent with recent evidence on individual European countries (Bartz and Winkler, 2016; Huber et al., 2017), the results indicate that during economic downturns the relationship between firm size and growth is almost unaffected (except for very small firms which show more resilience), but young firms, while

accounting for firm age and regression-to-the-mean bias when investigating employment dynamics throughout the business cycle. 

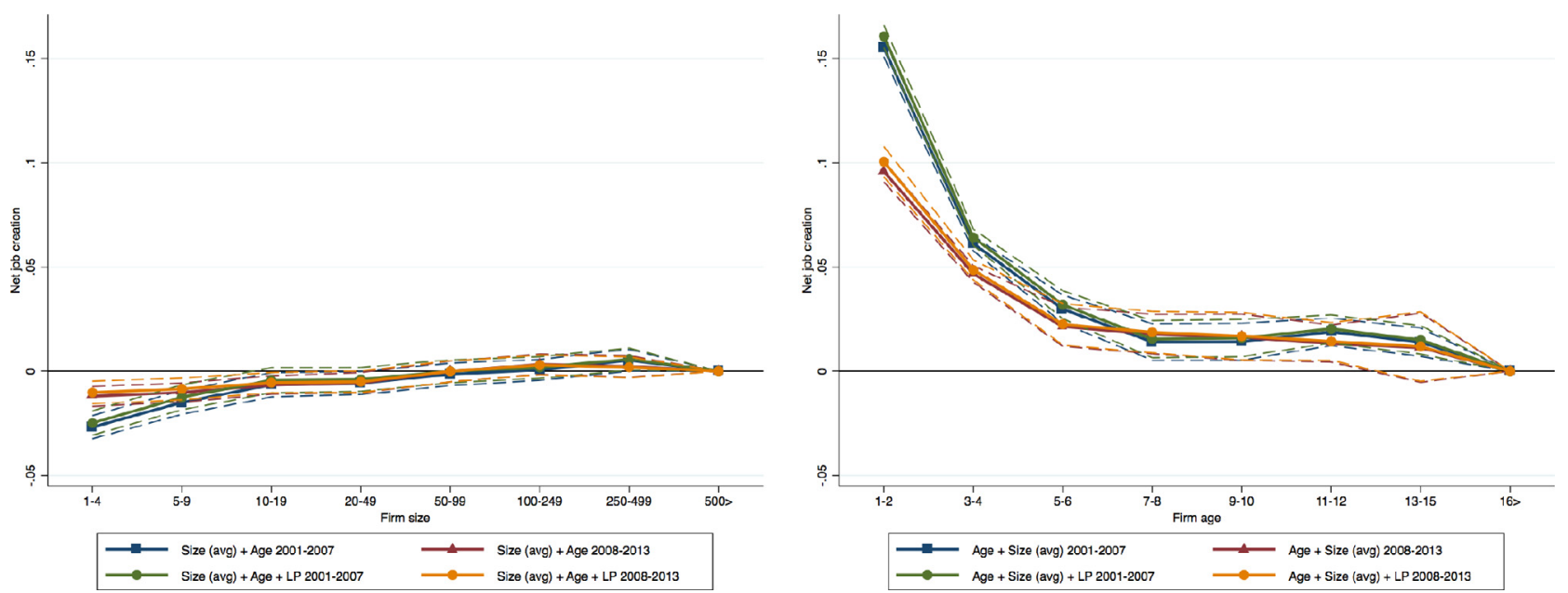

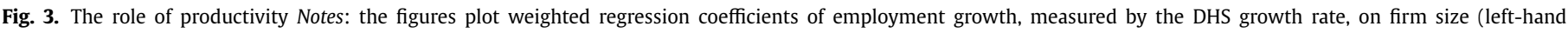

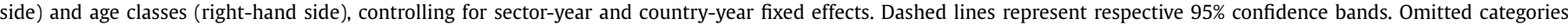

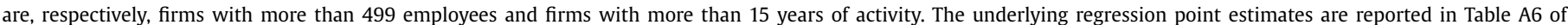
the Appendix in the Supplementary Materials.

remaining the most dynamic group of businesses, are the most affected by the crisis.

\subsection{The role of productivity}

We augment the baseline model by adding labour productivity to the RHS of Equation (1). The reason for this is twofold. First, the age-size-growth dynamics might be well influenced by market selection processes - more efficient firms are expected to grow more - and, by controlling for productivity, we intend to test whether this alters the age-size-growth relationships documented so far. Second, controlling for productivity in our specification allows us to test whether the sharp decline in employment growth rates experienced by young firms is actually due to their lower efficiency.

Operationally, we estimate Equation (1) using the average size classification and including the average labour productivity (measured as the log of value added ${ }^{15}$ over employees) over the period during which the growth rate is defined. This allows to minimise the impact of potential measurement error (Rijkers et al., 2014). ${ }^{16}$ The estimation results reported in Figure 3 indicate that labour productivity does not alter in any meaningful way the size-agegrowth relationship observed so far. Point estimates and patterns of statistical significance are largely unaltered by the inclusion of this variable. ${ }^{17}$

\footnotetext{
15 We do not have information regarding value added for around $24 \%$ of total firmyear observations. In order not to discard observations - and hamper the representativeness of the sample - we follow the internal imputation procedure outlined in Gal (2013). The best substitute for value added is using its definition based on factor incomes which entails adding up factor incomes going to employees and to capital owners. The empirical counterparts to these variables are the cost of employees and EBITDA. We internally impute value added by summing these variables for those firm-year observations with missing value-added. Gal (2013) shows that the internally imputed values show very high correlations with value added (0.98) for an average country and year. All monetary variables are deflated using the country-specific GDP deflators available from AMECO (http://ec.europa.eu/ economy_finance/ameco/user/serie/SelectSerie.cfm) under the item "Price deflator gross domestic product - OVGN".

16 As robustness test, we also replicated our analysis by using the base size classification and including a one-year lagged labour productivity measure and obtain results that are qualitatively similar.

17 If anything, we observe slightly higher coefficients for very young firms suggesting that, while they exhibit very high net job creation, they also tend to be less productive on average (Rijkers et al., 2014). However, these differences are not statistically significant.
}

The point estimates contained in Table A6 show an overall positive relationship between labour productivity and employment growth thus indicating that more efficient firms tend to grow faster (see column 2). However, the explanatory power of labour productivity is low as augmenting the model with this variable bears no meaningful variation in the $R^{2}$. This in line with previous evidence documenting the weak relationship between productivity and firm growth thus signalling a weaker than expected market selection (Bottazzi et al., 2010). Additionally, the previously documented decline in employment growth for young firms is robust to the inclusion of productivity suggesting that this is not determined by lower efficiency.

Finally, the results reveal that the positive effect of productivity on net job creation is larger and statistically significant in 2001-2007 whereas is smaller and not statistically significant during 2008-2013 (see Table A6: columns 3 to 6). This indicates that the "cleansing effect" does not seem to be at work (at least conditional on survival) in line with recent evidence such as Foster et al. (2016) for the US. This might be related to the presence of tight financial market conditions that would hinder the productivity enhancing effects of recessions and prove particularly detrimental to those firms that are in more need of external funding such as younger businesses (Robb and Robinson, 2012).

\subsection{The role of financial constraints}

We now focus on one of the potential mechanisms behind the negative impact of the recession on the most vulnerable firms, i.e. financial constraints.

In order to test whether the decline in net job creation experienced by very young firms is, at least in part, due to the difficulty for these firms in being granted credit, we rely on a proxy of external financial dependence (EFD) based on the seminal work of Rajan and Zingales (1998). The rationale behind such measure is that some industries tend to rely more on external finance for structural reasons (e.g. technological characteristics that evolve slowly with time). Hence, it is a (time-invariant) proxy for credit demand across industries which indicate those sectors that, in time of credit squeeze, might be more likely to experience financial constraints.

We use a proxy constructed using US data. There are two reasons for this choice. The first is that it provides an exogenous measure; the second is that, in order to calculate an EFD measure, 

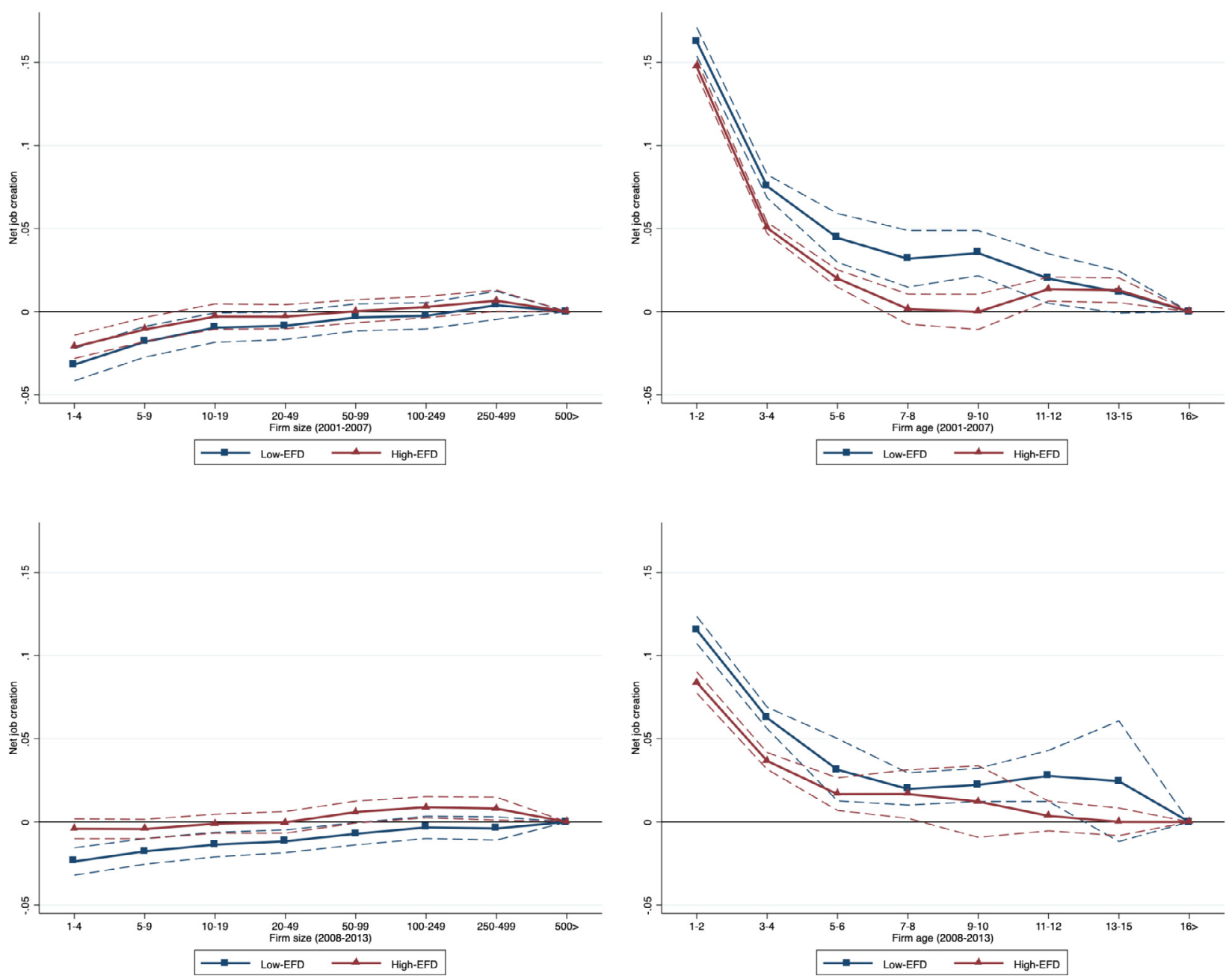

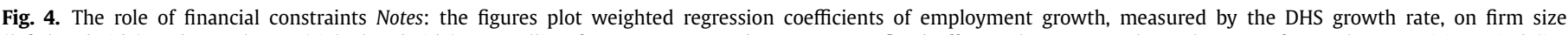

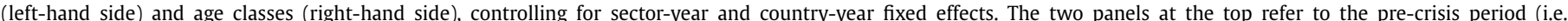

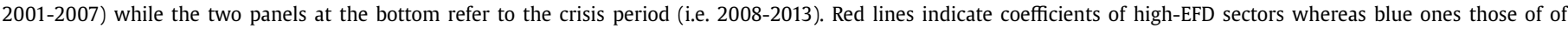

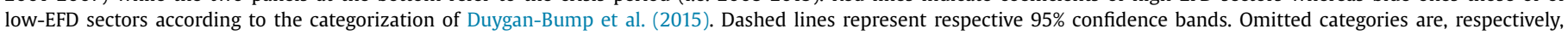

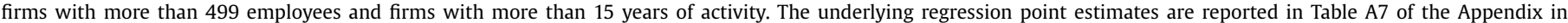
the Supplementary Materials.

we would need capital expenditures, which are are not available in Amadeus. The measure is drawn from the work of DuyganBump et al. (2015) who computed EFD across different sectors (both manufacturing and services) based on Compustat. In more detail, they use data during 1980-1996 and calculate EFD at the firm-level as the proportion of capital expenditures financed with external funds. A positive value indicates that firms must issue debt or equity to finance investments, whereas a negative value indicates that firms have free cash and therefore no external financing needs. They then use the median value across all firms within a 2-digit US SIC sector as the measure of financial dependence. Next, they partition the sample into high-EFD or low-EFD sectors whether the sector is above or below the median across industries. We are able to easily map the original classification to 2-digit NACE sectors thanks to the availability of US SIC classification of economic activities in Amadeus.

Based on this proxy for external financing needs, we estimate separate regressions for high-EFD as well as low-EFD sectors prior and during the double-dip recession. Figure 4 reports the results using the first EFD index (Duygan-Bump et al., 2015). The top panel refers to the pre-crisis period while the bottom panel refers to the crisis period. Results show that while the net job creation of young firms across high- and low-EFD sectors is very similar during 2001-
2007 (see top-right panel), these show a widened gap during the 2008-2013 (see bottom-right panel). In fact, during the crisis young firms (aged 1-2) operating in industries with higher financial dependence (red lines) experience a steeper decline in their growth rates if compared with firms with the age class but in less financially dependent sectors. Thus, these estimates provide an indication that the difficulty in accessing credit during the double-dip recession can explain the observed decline in employment growth rates for very young firms. ${ }^{18}$

\section{Extensions and robustness checks}

In this section we provide a series of extensions along with various robustness checks to test the sensitivity of the baseline estimates.

Sectoral heterogeneity. The above estimates may mask substantial heterogeneous effects of the crisis across different sectors. Prior research has in fact documented that sectors might respond differently to negative economic shocks (Stock and Watson, 1999)

\footnotetext{
18 We also augmented the models with labour productivity and find no qualitative change in the results which are available upon request.
} 
and that young firms might not be affected equally across sectors (Fort et al., 2013). For instance, young firms in manufacturing and high-tech sectors might be more exposed than those in other sectors given their higher financial needs (Aghion et al., 2012; Guiso, 1998). ${ }^{19}$ In order to investigate potential heterogeneous responses, we examine three macro-industries: manufacturing, services and high-tech ${ }^{20}$. We estimate Equation (1) separately for the three macro-industries. Results reported in Figure A2 indicate that, while young firms in all three macro-industries experience a considerable reduction in their growth rates, very young firms (age 1-2) in manufacturing and high-tech sectors display higher sensitivity to the economic downturn. In fact, their growth advantage relative to older firms during the pre-crisis period is practically halved during the double-dip recession (from around 13\% to 6-7\%). On the contrary, young firms in services, although they feature the highest growth rates before 2008 (in line with the evidence provided by Haltiwanger et al. (2013)), they do not experience such a drastic decrease in their growth rates (from $16 \%$ to $10.8 \%$ ). The fact that very young firms in manufacturing and high-tech firms are characterised by higher sensitivity might be due to several factors. For manufacturing firms, one possible explanation could be that these firms might require higher investments in tangible capital during their start-up phase. Given the scarce credit availability during recessionary years, they start with lower capital which results in lower collateral which further inhibits the possibility of accessing external credit and, in turn, reduces growth. Furthermore, during the financial crises banks might be in need to reduce their risk exposure and, therefore, opt for financing safer projects. This means that young high-tech firms, in light of the higher risk involved in their activities, find it more difficult to receive external financing during the recession (Paunov, 2012) causing a negative effect on their growth. Finally, some interesting but less remarkable differences emerge when it comes to firm size. Indeed, the positive relationship between size and growth observed in the aggregate estimates is mainly driven by services firms. The higher resilience of smaller firms during the recession is likewise driven by this sector. By contrast, manufacturing and high-tech are characterised by different dynamics before and during the double-dip recession. In these industries, smaller size classes tend to grow slightly faster if compared with large firms during the pre-crisis period (although the relationship is not necessarily linear). During the recession this pattern is somewhat less pronounced, with a minor decline in that is not statistically significant.

Financial crisis vs Sovereign debt crisis. In the main analysis we split the sample into pre-crisis (2001-2007) and crisis (2008-2013) periods. Since the latter was characterised by both the financial crisis and the sovereign debt crisis, we examined possible heterogeneous effects across the two recessionary periods by splitting our sample into three periods: pre-recessionary (2001-2007), financial crisis (2008-2010) and sovereign debt crisis (2011-2013). Results from this specification (see Figure A3) indicate that the decline in employment growth among very young firms during 2008-

\footnotetext{
19 Stock and Watson (1999) have documented how employment in manufacturing industries is more pro-cyclical than in others. Fort et al. (2013) report a higher sensitivity for young and small firms in those sectors connected to the housing market that experienced a collapse in the US during the Great Recession (i.e. constructions, retail trade, finance, insurance and services). Empirical evidence also corroborates the higher vulnerability of innovative firms during the recent recession (Lee et al., 2015) and it also suggests that young firms were more likely to discontinue innovative projects during the financial crisis relative to mature firms whereas firm size was unrelated to changes in innovation in crisis versus stable times (Paunov, 2012).

20 Manufacturing industries are those corresponding to NACE rev. 2 codes 20-32. Services industries are those corresponding to NACE rev. 2 codes 50-99. High-tech encompasses manufacturing high-technology and medium-high-technology sectors, and knowledge intensive service sectors based on the two-digit definition provided by Eurostat (http://ec.europa.eu/eurostat/cache/metadata/Annexes/htec_esms_ an3.pdf).
}

2013 is largely attributable to the financial crisis period. During the sovereign debt crisis, employment growth rates of firms aged 1-2 are still lower than the pre-crisis period although this difference is only marginal. This is consistent with the idea that not all recessions are alike and that their different nature might lead to different impacts (Fort et al., 2013).

Core vs Periphery. We also check whether the fall in the employment growth rates of young firms varies across core (Austria, Belgium, Finland, France, Germany) and peripheral countries (Greece, Ireland, Italy, Portugal, Spain). Consistent with the fact that the latter group of countries has suffered more during the doubledip recession and that, hence, younger firms in these economies might have been more severely affected, we find that employment growth rates exhibit a larger decline in peripheral than in core countries. In fact, very young firms in peripheral economies experienced a reduction in their growth rates of approximately $1 / 2$ while in core countries this figure is around 1/4 (see Figure A4).

Firm fixed effects. Throughout the paper, we always estimate employment-weighted OLS to facilitate comparison with relevant prior literature (Haltiwanger et al., 2013; Huber et al., 2017). Moreover, this econometric approach is motivated by the fact that we are interested in the differences between firms rather than within firms over time. Despite this, we re-run our analysis by employing OLS with firm fixed effects. Results, in line with the baseline estimates, indicate that young firms decreased their employment growth rates whereas smaller firms increased them during the recession (results are available upon request).

Different estimation samples. One possible concern with our results is that they could be driven by a handful of sectors that were disproportionately affected by the double-dip recession. We follow Siemer (2019) and Duygan-Bump et al. (2015) and replicate our analysis excluding the construction industry given that this was one of the most affected ones (especially in Southern Eurozone countries). The estimation results for the sample without constructions confirm the earlier findings (see Figure A5). Based on the same rationale, we also rerun our baseline models excluding another sector that has been hit particularly hard from the financial crisis, namely, real estate and we found no qualitative change in the results. Moreover, we rerun the main estimations without including Austria, Ireland and Portugal given that for these countries our sample features a low number of observations in the pre-crisis period. Estimation results obtained by removing these countries from our sample are practically unaffected (see Table A6).

Alternative financial constraint measure. In order to test the sensitivity of our findings, we employ an alternative measure of EFD. This is taken from the recent contribution of Siemer (2019) who exploits the 1998 Survey of Small Business Finance (SSBF) drawing on Cetorelli and Strahan (2006). This alternative measure is of particular interest given that it better captures bank dependence for smaller firms (i.e. US firms with less than 500 firms). We use the classification computed by Siemer (2019) who constructs bank dependence for each firm in the SSBF by calculating the share of assets financed with debt from financial institutions. Each 2-digit US SIC sector is then categorised into high-EFD or low-EFD in the same manner as before. Figure A7 reports the results using the second EFD index (Siemer, 2019) which are in line with what obtained in the baseline model.

Alternative productivity proxy. To check the findings concerning the role of productivity, we estimated the corresponding models using a TFP index instead of labour productivity. The former is computed using the well-known Levinsohn-Petrin method (Levinsohn and Petrin, 2003). ${ }^{21}$ Results show no noticeable variations to the ones shown in the main text, that is, augmenting

\footnotetext{
${ }^{21}$ All monetary variables are deflated using the GDP implicit deflators.
} 
the baseline model with TFP has a negligible effects on the agesize-growth relationships and does not indicate the presence of a cleansing effect of the recession during 2008-2013 (Table A8).

\section{Conclusions}

In this paper we investigate the impact of the 2008 double-dip recession on employment growth performances across firm size and age classes in the Eurozone. The results indicate that during the downturn young firms are more vulnerable than small firms, an interesting finding in light of the longstanding debate on the sources of employment growth in the economy, and on their behaviour against an exogenous shock. Notwithstanding the sharp drop in employment growth among young businesses, we find a relatively strong negative relationship between firm age and employment growth (Haltiwanger et al., 2013) even during a recessionary shock. In other words, young firms are still the most dynamic group of firms contributing to employment growth.

We also show that financial frictions increased the sensitivity of young firms to recessionary shocks and played a significant role in hampering their growth. Young firms in sectors characterised by high external financial dependence experienced a more marked slowdown relative to other sectors. This is an interesting, but also worrying result from a policy viewpoint: in the presence of capital market frictions, there is no guarantee that the more efficient firms will be more resilient to the crisis relative to less efficient ones. This may have highly undesirable consequences for the prospects of recovery if, as is plausible to expect, the worst affected firms are those with high innovative potential that makes businesses in search for external capital more informationally opaque. The finding is corroborated by the additional evidence we have produced on the high-tech segment of the economy, which is indeed more capital-intensive, but is also an important engine of future employment.

While one limitation of the study is that we cannot observe directly firm exits, our evidence on the effects of the double-dip recession on the employment growth of young firms is systematic and robust. Based on extant literature, the results we have presented on the negative impact of the recession on young firms are, if anything, underestimated. Recent contributions have indicated that start-ups founded in recessionary years have a higher probability of going bankrupt, relative to start-ups founded in nonrecessionary years (Deloof and Vanacker, 2018). Huber et al. (2017), who use Austrian data and adopt a methodology similar to ours, find that young firms decrease their employment growth during the Great Recession when considering firms conditional on survival. When including the exit margin they show that this decrease tends to be even larger because young businesses suffer from higher exit probabilities during the recession. This is not the case for small firms given that these experience a relative increase in their growth rates while their exit probabilities were unaltered in the recessionary years. Somewhat differently, Colciago et al. (2019), based on US data, show that the contribution to job destruction of small and young exiting firms do not vary considerably across precrisis and crisis years.

The paper has addressed one channel through which young firms are hit harder during recessions, namely, financial frictions. This reduction in the growth rates of younger firms might also stem from other factors that we do not observe with the data at our disposal. For instance, one aspect that future research might address deals with individuals'self-selection into entrepreneurship. That is, individuals starting up a business during a recession might respond to a lack of available job opportunities and establish a firm out of necessity as opposed to a business opportunity. If that were the case, the reduced quality and growth orientation of young firms established during downturns might concur in explaining the decline in their growth rates.

From a policy viewpoint the effect of the crisis on younger firms in the 'periphery' of the Eurozone is a particular source of concern because of the role these firms can play in the recovery period if market selection was able to differentiate between relatively better and worse firms (and we do not find evidence of this). It is an open and urgent question whether this pattern may also characterise the recession potentially caused by the COVID-19 pandemic in laggard countries.

To conclude, our findings highlight the central role of age when disentangling the heterogeneous effects of recessions on firms. In light of this, given that most public policies as well as the general debate still revolve around small firms, we argue that it would beneficial to shift the focus towards the support of younger businesses and their growth since the unfavourable conditions at entry, especially during recessions, could have permanent effects on their subsequent performance with far-reaching repercussions on aggregate job creation and macroeconomic competitiveness. This is especially relevant at the time of writing since early indicators suggest that startup activity has been heavily disrupted by the COVID19 outbreak (Sedlacek and Sterk, 2020). Monitoring how young firms activity is responding to the COVID-19 crisis is paramount to the recovery and represents a central policy concern. Targeted interventions to avoid i) young firms growing less than they would have in normal times and ii) a 'missing generation of firms' might be important to prevent the potentially long-lasting effects on aggregate employment.

\section{Declaration of Competing Interest}

The authors declare that they have no known competing financial interests or personal relationships that could have appeared to influence the work reported in this paper.

\section{Acknowledgements}

We are grateful to the Editor and two anonymous referees for invaluable comments. We also thank Alex Coad and Federico Tamagni for helpful suggestions. The authors acknowledge the support by the European Unions Horizon 2020 research and innovation program under grant agreement No. 822781 - GROWINPRO.

\section{Supplementary material}

Supplementary material associated with this article can be found, in the online version, at doi:10.1016/j.strueco.2020.11.002.

\section{References}

Acs, Z.J., Audretsch, D.B., Strom, R.J., 2009. Entrepreneurship, growth, and public policy. Cambridge University Press.

Aghion, P., Askenazy, P., Berman, N., Cette, G., Eymard, L., 2012. Credit constraints and the cyclicality of R\&D investment: Evidence from France. Journal of the European Economic Association 10 (5), 1001-1024. doi:10.1111/j.1542-4774.2012. 01093.x.

Alviarez, V., Cravino, J., Levchenko, A.A., 2017. The growth of multinational firms in the Great Recession. Journal of Monetary Economics 85, 50-64. doi:10.1016/j. jmoneco.2016.11.006.

Angrist, J.D., Pischke, J.-S., 2009. Mostly harmless econometrics: An empiricist's companion. Princeton University Press.

Anyadike-Danes, M., Bjuggren, C.-M., Gottschalk, S., Hölzl, W., Johansson, D., Maliranta, M., Myrann, A., 2015. An international cohort comparison of size effects on job growth. Small Business Economics 44 (4), 821-844.

Audretsch, D.B., 2002. The dynamic role of small firms: Evidence from the us. Small business economics 18 (1-3), 13-40.

Bartz, W., Winkler, A., 2016. Flexible or fragile? The growth performance of small and young businesses during the global financial crisis-evidence from Germany. Journal of Business Venturing 31 (2), 196-215. doi:10.1016/j.jbusvent.2015.10. 002. 
Birch, D.G., 1987. Job creation in america: How our smallest companies put the most people to work. University of Illinois at Urbana-Champaign's Academy for Entrepreneurial Leadership Historical Research Reference in Entrepreneurship.

Birch, D.L., 1981. Who creates jobs? The public interest 65, 3.

Bottazzi, G., Dosi, G., Jacoby, N., Secchi, A., Tamagni, F., 2010. Corporate performances and market selection: some comparative evidence. Industrial and Corporate Change 19 (6), 1953-1996. doi:10.1093/icc/dtq063.

Bottazzi, G., Secchi, A., Tamagni, F., 2014. Financial constraints and firm dynamics. Small Business Economics 42 (1), 99-116.

Cetorelli, N., Strahan, P.E., 2006. Finance as a barrier to entry: Bank competition and industry structure in local us markets. The Journal of Finance 61 (1), 437-461. doi:10.1111/j.1540-6261.2006.00841.x.

Chodorow-Reich, G., 2014. The employment effects of credit market disruptions: Firm-level evidence from the 2008-9 financial crisis. The Quarterly Journal of Economics 129 (1), 1-59. 10.1093/qje/qjt031

Coad, A., 2009. The growth of firms: A survey of theories and empirical evidence. Edward Elgar Publishing.

Coad, A., 2018. Firm age: a survey. Journal of Evolutionary Economics 28 (1), 13-43. doi:10.1007/s00191-016-0486-0.

Coad, A., Segarra, A., Teruel, M., 2013. Like milk or wine: Does firm performance improve with age? Structural Change and Economic Dynamics 24, 173-189.

Colciago, A., Lindenthal, V., Trigari, A., 2019. Who creates and destroys jobs over the business cycle? De Nederlandsche Bank Working Paper March (628).

Criscuolo, C., Gal, P.N., Menon, C., 2017. Do micro start-ups fuel job creation? Crosscountry evidence from the dynemp express database. Small Business Economics 48 (2), 393-412. doi:10.1007/s11187-016-9778-X.

Davis, S.J., Haltiwanger, J.C., Schuh, S., et al., 1996. Job creation and destruction. MIT Press Books 1.

Deloof, M., Vanacker, T., 2018. The recent financial crisis, start-up financing, and survival. Journal of Business Finance \& Accounting.

Duygan-Bump, B., Levkov, A., Montoriol-Garriga, J., 2015. Financing constraints and unemployment: evidence from the Great Recession. Journal of Monetary Economics 75, 89-105. doi:10.1016/j.jmoneco.2014.12.011.

Fairlie, R.W., Fossen, F.M., 2019. Defining opportunity versus necessity entrepreneurship: Two components of business creation. Technical Report. National Bureau of Economic Research.

Fernandes, A.P., Ferreira, P., 2017. Financing constraints and fixed-term employment: Evidence from the 2008-9 financial crisis. European Economic Review 92, 215238. doi:10.1016/j.euroecorev.2016.12.009.

Fort, T.C., Haltiwanger, J., Jarmin, R.S., Miranda, J., 2013. How firms respond to business cycles: The role of firm age and firm size. IMF Economic Review 61 (3), 520-559. doi:10.1057/imfer.2013.15.

Foster, L., Grim, C., Haltiwanger, J., 2016. Reallocation in the Great Recession: cleansing or not? Journal of Labor Economics 34 (S1), S293-S331. doi:10.1086/682397.

Gal, P.N., 2013. Measuring total factor productivity at the firm level using oecd-orbis. OECD Economics Department Working Papers 1049.

Gertler, M., Gilchrist, S., 1994. Monetary policy, business cycles, and the behavior of small manufacturing firms. The Quarterly Journal of Economics 109 (2), 309340. doi: $10.2307 / 2118465$.

Grazzi, M., Moschella, D., 2018. Small, young, and exporters: New evidence on the determinants of firm growth. Journal of Evolutionary Economics 28 (1), 125152. doi:10.1007/s00191-017-0523-7.

Guiso, L., 1998. High-tech firms and credit rationing. Journal of Economic Behavior \& Organization 35 (1), 39-59

Hadlock, C.J., Pierce, J.R., 2010. New evidence on measuring financial constraints: Moving beyond the kz index. The Review of Financial Studies 23 (5), 1909-1940. doi:10.1093/rfs/hhq009.

Haltiwanger, J., Jarmin, R.S., Miranda, J., 2013. Who creates jobs? Small versus large versus young. Review of Economics and Statistics 95 (2), 347-361. doi:10.1162/ REST_a_00288.

Haltiwanger, J.C., Hyatt, H.R., Kahn, L.B., McEntarfer, E., 2018. Cyclical job ladders by firm size and firm wage. American Economic Journal: Macroeconomics 10 (2), 52-85.

Huber, P., Oberhofer, H., Pfaffermayr, M., 2017. Who creates jobs? Econometric modeling and evidence for Austrian firm level data. European Economic Review 91, 57-71. doi:10.1016/j.euroecorev.2016.09.008.
Hurst, E., Pugsley, B.W., 2011. What do small businesses do? Brookings Papers on Economic Activity 42 (2).

Jovanovic, B., 1982. Selection and the evolution of industry. Econometrica: Journal of the Econometric Society 649-670 stable/1912606.

Kalemli-Ozcan, S., Sorensen, B., Villegas-Sanchez, C., Volosovych, V., Yesiltas, S., 2015. How to construct nationally representative firm level data from the ORBIS global database. Technical Report. National Bureau of Economic Research.

Kelley, D.J., Bosma, N., Amorós, J.E., 2011. Global entrepreneurship monitor: Global report 2010. Global Entrepreneurship Research Association.

Kudlyak, M., Sánchez, J.M., 2017. Revisiting the behavior of small and large firms during the 2008 financial crisis. Journal of Economic Dynamics and Control 77, 48-69. doi:10.1016/j.jedc.2017.01.017.

Lawless, M., 2014. Age or size? Contributions to job creation. Small Business Economics 42 (4), 815-830. doi:10.1007/s11187-013-9513-9.

Lee, N., Sameen, H., Cowling, M., 2015. Access to finance for innovative smes since the financial crisis. Research policy 44 (2), 370-380. doi:10.1016/j.respol.2014. 09.008.

Lee, Y., Mukoyama, T., 2015. Entry and exit of manufacturing plants over the business cycle. European Economic Review 77, 20-27. doi:10.1016/j.euroecorev.2015. 03.011.

Levinsohn, J., Petrin, A., 2003. Estimating production functions using inputs to control for unobservables. The Review of Economic Studies 70 (2), 317-341. doi:10.1111/1467-937X.00246.

Moreira, S., 2017. Firm Dynamics, Persistent Effects of Entry Conditions, and Business Cycles. Working Papers. Center for Economic Studies, U.S. Census Bureau.

Moscarini, G., Postel-Vinay, F., 2012. The contribution of large and small employers to job creation in times of high and low unemployment. The American Economic Review 102 (6), 2509-2539. 10.1257/aer.102.6.2509

Navaretti, G.B., Castellani, D., Pieri, F., 2014. Age and firm growth: evidence from three european countries. Small Business Economics 43 (4), 823-837.

Neumark, D., Wall, B., Zhang, J., 2011. Do small businesses create more jobs? New evidence for the United States from the National Establishment Time Series. The Review of Economics and Statistics 93 (1), 16-29. doi:10.1162/REST_a_00060.

Paunov, C., 2012. The global crisis and firms investments in innovation. Research Policy 41 (1), 24-35. doi:10.1016/j.respol.2011.07.007.

Peric, M., Vitezic, V., 2016. Impact of global economic crisis on firm growth. Small Business Economics 46 (1), 1-12. doi:10.1007/s11187-015-9671-z.

Popov, A., Rocholl, J., 2018. Do credit shocks affect labor demand? evidence for employment and wages during the financial crisis. Journal of Financial Intermediation 36, 16-27. doi:10.1016/j.jfi.2016.10.002.

Rajan, R.G., Zingales, L., 1998. Financial dependence and growth. The American Economic Review 559-586. http://www.jstor.org/stable/116849

Rijkers, B., Arouri, H., Freund, C., Nucifora, A., 2014. Which firms create the most jobs in developing countries? Evidence from Tunisia. Labour Economics 31, 84102. doi:10.1016/j.labeco.2014.10.003.

Robb, A., Robinson, D., 2012. The capital structure decisions of startup firms. Review of Financial Studies 1 (1), 1-27.

Sedláček, P., Sterk, V., 2017. The growth potential of startups over the business cycle. The American Economic Review 107 (10), 3182-3210. 10.1257/aer.20141280

Sedlacek, P., Sterk, V., 2020. Startups and employment following the covid-19 pandemic: A calculator.

Siemer, M., 2019. Employment effects of financial constraints during the Great Recession. The Review of Economics and Statistics 101 (1), 16-29. doi:10.1162/ rest_a_00733.

Stock, J.H., Watson, M.W., 1999. Business cycle fluctuations in us macroeconomic time series. Handbook of macroeconomics 1, 3-64. doi:10.1016/S1574-0048(99) 01004-6.

Varum, C.A., Rocha, V.C., 2013. Employment and smes during crises. Small Business Economics 40 (1), 9-25. doi:10.1007/s11187-011-9343-6.

Zarutskie, R., Yang, T., 2017. How did young firms fare during the Great Recession? Measuring Entrepreneurial Businesses: Current Knowledge and Challenges 75, 253. 